\title{
The Eastern Link: The Largest Archaeological Excavation Program in the History of Sweden?
}

\author{
Magnus Djerfsten \\ Swedish Transport Administration
}

A new high-speed railway is to be built between the small community of Järna, $30 \mathrm{~km}$ southwest of Stockholm, and the city of Linköping in the county of Östergötland. The railway will pass through the parts of Sweden with the highest density of archaeological remains. We estimate that nearly 500 ancient monuments will need to be excavated, from the earliest Mesolithic period to remains and artefacts from the nineteenth century. Within a few years the number of archaeological excavations will increase enormously and during the years 2023 to 2025 the project will likely need up to 250 archaeologists working at the same time for field excavations. The excavations are going to be a major logistical challenge but also a great opportunity to reach new results. This is in part due to the duration of the coming investigation but also the large variety of ancient monuments.

As an example, approximately 30 grave fields will be excavated, mostly from the Iron Age but also a number from the Late Bronze Age. Right now the first of many grave fields is being excavated, just north of the city Norrkoping. It consists of about I 80 graves from the Late Iron Age, making it one of the largest of the period ever to be excavated in Östergötland, although larger grave fields are known in the region.

Even though the archaeological process is at an early stage there are some interesting results already. One example is the large number of Stone Age settlements discovered in Östergötland - over one hundred so far. Settlements, mainly Mesolithic, have been discovered both in the flatter agricultural part of central Östergötland and in the hillier woodlands of Kolmården in the northern part of the region. Further Stone Age settlements 
have also been discovered in Södermanland county and south of the city of Södertälje. We believe that as many as one hundred Stone Age settlements will be fully excavated during the coming years and this will not only be a fantastic opportunity to undertake statistical comparisons between the different landscapes in this part of Sweden, but also to generate large amounts of material for further analyses. So far, the results correlate to previous evidence showing that very few Stone Age settlements can be identified on land over $85 \mathrm{~m}$ above sea-level, which are the areas that emerged from the sea as a result of the ongoing land-rise before about 8000 B.C. The upcoming excavations may reveal whether or not there was a population in this region before that time - or was the population so small that no traces can be found?

In connection with this field work, the Swedish Transport Administration, Stockholm University, and the National Historical Museums are carrying out research on how the shoreline has changed throughout history. This work will produce updates to the mapping from the Geological Survey of Sweden concerning shoreline changes during prehistory. In the coming excavations we will, for example, have access to more precise dating of Stone Age shoreline settlements which lack organic materials.

A connected project concerning wetland archaeology is also starting up right now. This kind of research has previously not had a strong position in Swedish archaeology and we hope to sharpen this discipline. The project will include analyses of where remains and artefacts can be found, the sorts of findings we can expect and the methods we may use in different kinds of wetlands. A number of wetland excavations have already begun, using low-frequency ground penetrating radar with satisfactory results. Near Linköping a wooden structure from the early sixteenth century was found and a survey in a wetland south of Norrköping produced a large Iron Age road. 